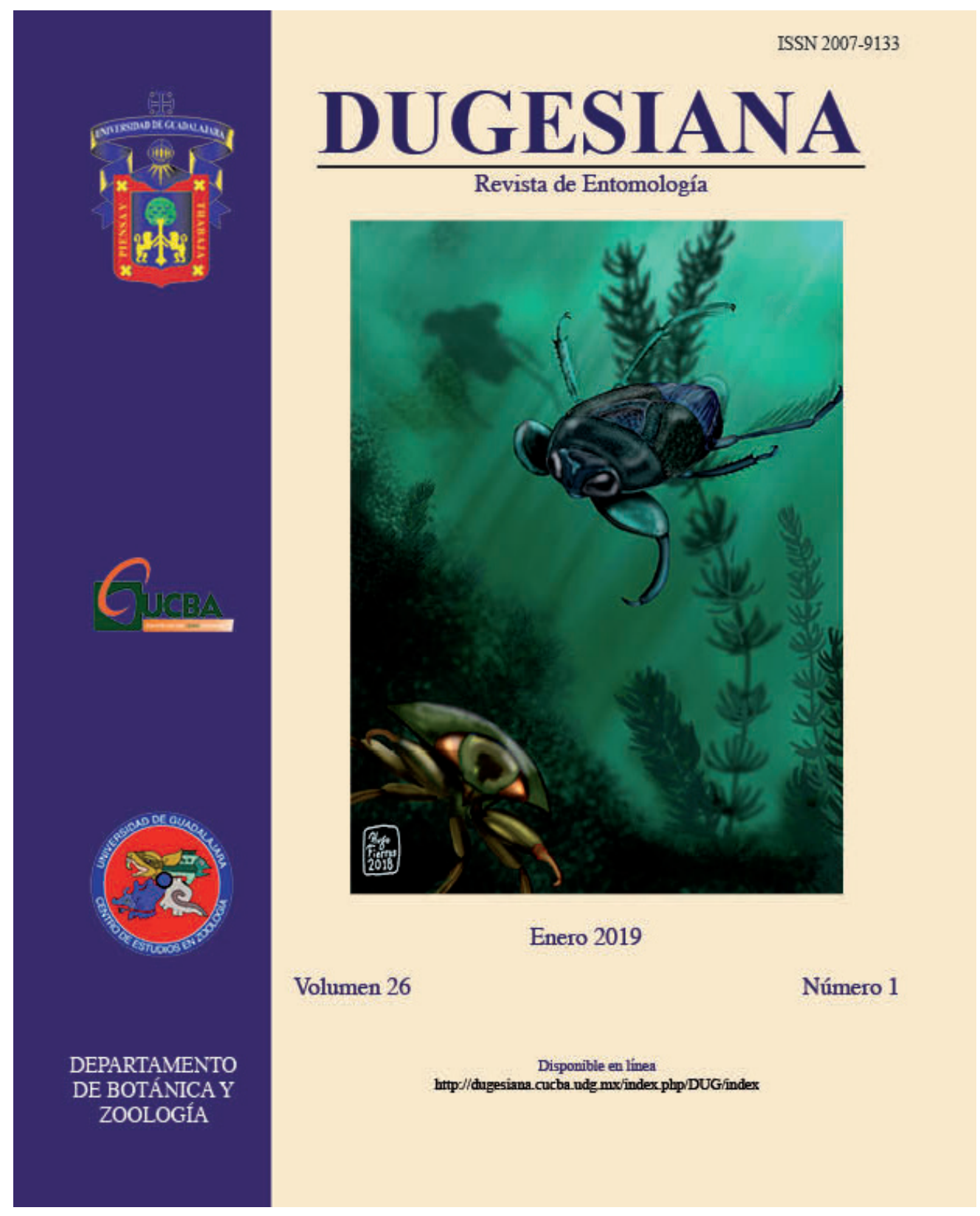

DUGESIANA, Año 26, No.1, 2019 (primer semestre de 2019) es una publicación Semestral editada por la Universidad de Guadalajara, a través del Centro de Estudios en Zoología, por la División de Ciencias Biológicas y Ambientales, CUCBA. Km. 15.5 carr. a Nogales, Predio Las Agujas s/n, Nextipac, C.P. 45100. Zapopan, Jalisco, México. Tel. 37771150, http://dugesiana.cucba.udg.mx/index.php/DUG/index, glenusmx@gmail.com, Editor responsable: José Luis Navarrete Heredia. Reserva de Derechos al Uso Exclusivo 04-2009-062310115100-203, ISSN: 2007-9133, otorgados por el Instituto Nacional del Derecho de Autor. Responsable de la última actualización de este número: José Luis Navarrete Heredia, Editor y Ana Laura González-Hernández, Asistente Editorial. Fecha de la última modificación 1 de enero de 2019, con un tiraje de un ejemplar.

Las opiniones expresadas por los autores no necesariamente reflejan la postura del editor de la publicación.

Queda estrictamente prohibida la reproducción total o parcial de los contenidos e imágenes de la publicación sin previa autorización de la Universidad de Guadalajara. 


\title{
Two new species of Epipsocus Hagen, with forewing vein M3 forked (Psocodea: Psocomorpha: Epipsocidae)
}

\section{Dos nuevas especies de Epipsocus Hagen, con la vena M3 de la ala anterior bifurcada (Psocodea: Psocomorpha: Epipsocidae)}

\author{
Alfonso N. García Aldrete \\ Departamento de Zoología, Instituto de Biología, Universidad Nacional Autónoma de México, Apartado Postal \\ 70-153, CdMx, MÉXICO. E-mail: anga@ib.unam.mx
}

\begin{abstract}
Two species of Epipsocus Hagen, one from Costa Rica and the other from Mexico, are here described and illustrated; they are apomorphic, in having the forewing $\mathrm{M}$ dichotomously branched, thus differing from the pattern of caeciliusid venation of most of the species of Epipsocus. Other forewing venation anomalies in Epipsocus are presented.

Key words: 'Psocoptera', taxonomy, wing venation anomalies, Costa Rica, Mexico.

\section{RESUMEN}

Dos especies de Epipsocus Hagen, una de Costa Rica y la otra de México, son aquí descritas e ilustradas: son apomórficas, por tener la vena $\mathrm{M}$ del ala anterior dicotómicamente ramificada, en lo que difieren del patrón de venación caeciliúsida de la mayoría de las especies de Epipsocus. Se presentan también otras anomalías en la venación de las alas anteriores de Epipsocus.

Palabras clave: 'Psocoptera', taxonomía, anomalías de venación, Costa Rica, México.
\end{abstract}

Most of the known species of Epipsocus Hagen (see Lienhard \& Smithers, 2002; Psocodea.speciesfile.org), have caeciliusid wing venation (forewing Rs of two branches, $M$ three branched, hindwing Rs of two branches, $M$ unbranched), this being the plesiomorphic condition in the genus (see below, under Discussion).

I take here the opportunity to comment on some of the described species of Epipsocus: E. africanus Smithers, and $E$. rhabdolepis $\mathrm{Li}$, according to their phallosomes, do not belong in Epipsocus, as defined by Mockford (1998); E. argentinus Badonnel, was described on basis of a larva, and thus it lacks information on wing venation; E. fasciicornis Okamoto is a pseudocaeciliid (Yoshizawa, in litt., 2003). E. hageni Banks, and E. marginatus Enderlein, have been categorized as incerta sedis by Mockford (1998), E. pinnatus Enderlein, and E. viiv Enderlein are not clearly assignable in Epipsocus, and there is no information on wing venation in E. euryocephalus $\mathrm{Li}$, E. scotothoracalis $\mathrm{Li}$, E. spatulatus $\mathrm{Li}$, E. stictus $\mathrm{Li}$, and E. xanthotoracalis $\mathrm{Li}$.

I describe in this paper two species of Epipsocus that have the forewing $\mathrm{M}$ dichotomously branched (with M3 forked); one is from Guanacaste, Costa Rica, and the other is from the Chimalapas area, in Oaxaca, Mexico. They are assigned in Epipsocus because the male has the phallosome typical of the genus, and because the female gonapophyses have v1, that lacks in Mesepipsocus, the sister genus to Epipsocus (Casasola González, 2006; Casasola González \& García Aldrete, 2002).

\section{MATERIAL AND METHODS}

One female of the Costa Rican species, and two males and one female of the Mexican species were available for study. All the specimens were dissected in $80 \%$ ethanol, and their parts (heads, right wings and legs, and genitalia), were mounted on slides in Canada balsam, following standard procedures. Parts on the slides were measured with a filar micrometer; abbreviations of parts measured are the following: FW, HW: lengths of right fore- and hind- wings, F, T, t1, t2: lengths of femur, tibia and tarsomeres 1 and 2 of right hind leg, ctt1: number of ctenidobothria on $\mathrm{t} 1, \mathrm{Mx} 4$ : length of fourth palpomere of right maxillary palpus, $\mathrm{fl} \ldots$ fn: lengths of flagellomeres $1 \ldots n$ of right antenna, IO, D and d: minimum distance between compound eyes, anteroposterior diameter, and transverse diameter, respectively, of right compound eye, on dorsal view of head. PO: $d / D$. The types are deposited in the National Collection of Insects (CNIN), Zoology Department, Instituto de Biología, Universidad Nacional Autónoma de México, Mexico City.

\author{
RESULTS \\ Family Epipsocidae Pearman \\ Genus Epipsocus Hagen \\ Epipsocus moroni n. sp. Female \\ (Figs 1-5) \\ http://zoobank.org/147EC14A-F364-477F-B9EE- \\ 947CA1AA3840
}

Diagnosis. Differing from the described species of Epipsocus, in having the forewing $\mathrm{M}$ dichotomously branched (M3 forked).

Color (in 80\% ethanol). Body pale brown. Compound eyes black, ocelli hyaline, without centripetal pigmented crescents. Wings (Fig. 1) almost hyaline, pale brown, with veins dark brown; forewing: pterostigma with an anterior dark brown band, a dark spot at distal end of veins, and at confluence of $\mathrm{Cu} 2-\mathrm{A}$. Abdomen whitish, with brown subcuticular rings, less pigmented ventrally.

Morphology. Outer cusp of lacinial tip broad, with six denticles (Fig. 2). Forewing pterostigma long, narrow 
anteriorly, wider in the middle; $\mathrm{R} 2+3$ and $\mathrm{R} 4+5$ flexuous, longer than Rs; M with M3 branched. Areola postica low, apically rounded, four times as wide as tall (Fig. 1). Subgenital plate broad, setose, slightly projected posteriorly in the middle, pigmented area concave anteriorly (Fig. 3). Gonapophyses: v1 long, slender, acuminate, v2 +3 with a stout, blunt ended heel anteriorly, $\mathrm{v} 3$ a distinct, elongate lobe on side of v2, bearing 8-9 long setae, distal process anteriorly dilated, long, slender, pointed, with a field of microspines anteriorly (Fig. 5). Ninth sternum unpigmented (Fig. 5). Paraprocts (Fig. 4) broad, almost semicircular, setose, with elliptic sensory fields bearing 26-27 trichobothria on basal rosettes. Epiproct (Fig. 4) wide, rounded posteriorly, with a dense field of setae posteriorly, a field of microspines on anterior border of distal third, three long setae mesally on proximal third, other setae as illustrated.

Measurements. FW: 1712, HW: 1334, F: 1010, T: 1624, f1: 739, IO: 498, D: 345, d: 203, IO/d: 2.45, PO: 0.58 .

Type locality. Holotype female. COSTA RICA. Guanacaste Province. Punta Santa Elena. Cloud Forest Reserve, 1700 m. 8.IX.1998. Charles W. and Lois B. O'Brien.

Etymology. This species is dedicated, in memoriam, to Dr. Miguel Angel Morón Ríos, in recognition to his vast and important contributions to the study of Scarabeoidea, at the Instituto de Ecología A. C., in Jalapa, Veracruz, Mexico.

\section{Epipsocus reyesi $\mathbf{n}$. sp.} (Figs 6-13)

http://zoobank.org/004AFD13-0972-4DCD-8F80DD2333D06F49

Diagnosis. It differs from E. moroni n. sp., in having the forewing pterostigma less elongate, in having the subgenital plate with sides converging to the apex, with the pigmented area less concave anteriorly, and in having the anterior heel of v2+3 longer, slender and distally acuminate.

Male. Color (in $80 \%$ ethanol). Body reddish brown. Compound eyes black, ocelli hyaline, with ochre centripetal crescents. Head pattern (Fig. 8). Maxillary palps, antennae and legs brown. Wings hyaline, with a slight reddish hue. Forewing pterostigma with a proximal and a distal brown band. Veins brown, with a brown spot at wing margin. Abdomen whitish, with dark brown, transverse subcuticular bands on tergum, sternum almost unpigmented.

Morphology. Outer cusp of lacinial tip broad, with fivesix denticles. Forewing venation (Fig. 6), M dichotomously branched, areola postica low, elongate. Hindwing (Fig. 6). Hypandrium wide, setose, posteriorly straight, with a field of macrosetae on each corner (Fig. 8). Phallosome (Fig. 11), with posterior projection of aedeagal arch wide, endophallus membranous. Paraprocts (Fig. 7), broad, with setae as illustrated, sensory fields elliptic, bearing 26-28 setae on basal rosettes. Epiproct (Fig. 7) trapeziform, with three macrosetae next to anterior border, a row of three large setae along posterior border, and a field of setae mesally and postero-laterally.

Measurements. FW: 4180, HW: 2992, F: 382, T: 692, t1: 318, t2: 90, t3: ctt1: 33, Mx4: 251, f1: 1110, f2: 1031, f3: 799, IO: 294, D: 337, d: 225, IO/d: 1.30, PO: 0.66.

Female. Color (in $80 \%$ ethanol). Same as the male.

Morphology. Outer cusp of lacinial tip and wing venation as in the male. Subgenital plate (Fig. 10) broadly triangular, setose, with the apex rounded, pigmented area concave anteriorly. Gonapophyses (Fig. 12): v1 long, slender, acuminate; v2+3 anteriorly with a long, slender, sclerotized heel, v3 an elongate, distinct lobe on v2, bearing a field of 8-10 long setae, distal process anteriorly dilated, posteriorly slender, acuminate, both covered with microsetae, ninth sternum unpigmented, membranous, with spermapore located posteriorly. Paraprocts (Fig. 13), broad, setose, sensory fields elliptic, with 29-30 trichobothria on basal rosettes. Epiproct (Fig. 13) trapeziform, with three mesal macrosetae next to anterior border, a field of mesal and postero-lateral setae, and a row of long setae along posterior border.

Measurements. FW: 4357, HW: 3141, F: 399, T: 689, t1: 321, t2: 94, t3: ctt1: 33, f1: 975, f2: 1033, f3: 784, IO: 392, D: 312, d: 212, IO/d: 1.84, PO: 0.67.

Type locality. Holotype male. MEXICO. Oaxaca. 4 km N of Díaz Ordaz, San Miguel Chimalapa, $16^{\circ} 44.026^{\prime}$ N: $94^{\circ} 11.975^{\prime} \mathrm{W} .1512$ m. 20.X.2003. On rock wall with abundant lichens. J. A. Casasola González. Paratypes: 1 male, 1 female. Same data as the holotype.

Etymology. This species is dedicated in memoriam, to Dr. Pedro Reyes Castillo, of the Instituto de Ecología, A. C., of Jalapa, Veracruz, Mexico, who devoted his life to the study of Passalidae, area in which his many contributions are seminal.

\section{DISCUSSION}

The type species of Epipsocus, E. avus (Roesler), from Tertiary amber (see Enderlein, 1911), has the wing venation caeciliusid, this being the plesiomorphic condition, found in most of the recent species of Epipsocus. Two species deviate from this pattern: E. fuscareolatus New, from the Reserva Florestal Ducke, near Manaus, Amazonas, Brazil, has the forewing Rs of three branches, and $\mathrm{M}$ of four branches, not dichotomously divided (see New, 1980); E. opticus New \& Thornton, from The Peruvian Río Tambopata Reserve, also within the Amazon Basin, has the forewing $\mathrm{M}$ of four branches, not dichotomously divided (see New \& Thornton, 1988).

The two species here described, have the forewing $M$ dichotomously branched (with M3 forked) representing an apomorphic condition in Epipsocus, this pattern of venation is common in species of Mesepipsocus Badonnel, also observed in species of Edmockfordia García Aldrete, Mesepipsocoides García Aldrete \& Casasola González, and in the ptiloneurid genus Triplocania Roesler (see SilvaNeto et al., 2014; González Obando et al., 2017).

In undescribed species of Epipsocus, the following wing venation anomalies have been observed (Figs 14-19): forewing venation caeciliusid, vein stubs as illustrated, with crossvein areola postica-M (Fig. 14. ECUADOR. Napo. Waorani Ethnic Reserve, male), forewing $M$ dichotomously branched, vein stubs on $\mathrm{R} 2+3$ and $\mathrm{R} 4+5$ (Fig. 15. ECUADOR. Napo. Waorani Ethnic Reserve, female), forewing Rs three-branched, $M$ three branched (Fig. 16. BRAZIL. Amazonas. Río Purus, male), forewing Rs unbranched, $\mathrm{M}$ of four branches (Fig. 17. BRAZIL. Pará. Oriximiná. Río Trombetas, male), forewing Rs of five branches, a crossvein joining Rs and pterostigma, M five-branched (Fig. 18. BRAZIL. Amazonas. Manaus. University Campus, female), forewing Rs three branched, 
M five branched [M3 three branched] (Fig. 19. ECUADOR. Napo. Waorani Ethnic Reserve, female).

E. moroni García Aldrete is the first species of Epipsocus recorded in Costa Rica, and E. reyesi García Aldrete is the third species of Epipsocus recorded in Mexico, together with E. bullocki García Aldrete, and E. petenensis Mockford. These two species raise to 39 the number of the species in the genus, not considering in it the species E. africanus Smithers, E. fasciicornis Okamoto and E. rhabdolepis Li. Since a major difference between Epipsocus and Mesepipsocus is the lack of v1 in the latter, it is likely that some of the species known only from males in Epipsocus may belong in Mesepipsocus (e.g. E. acanthus New, E. argutus New, E. atratus New, E. badonneli Mockford, E. beguiristaini Williner, E. blandus New \& Thornton, E. foliatus Mockford, E. fuscareolatus New, E. maculithorax New, E. opticus New \& Thornton, E. pennyi New, E. pereirai Badonnel, E. phaeus New, E. roraimensis Mockford, E. serenus Roesler, E. stigmaticus Mockford, and E. verrucosus New).

\section{ACKNOWLEDGMENTS}

I thank Oscar Saenz Manchola (Posgrado en Ciencias Biológicas, UNAM), for support with the illustrations; Javier García Figueroa (Instituto de Biología, UNAM) took the measurements of E. moroni García Aldrete. J. A. Casasola González (Universidad de la Sierra Juárez, Ixtlán, Oaxaca), donated for study the specimens of $E$. reyesi García Aldrete. I thank Instituto de Biología, UNAM, for continuous research support.

Recibido: 4 de octubre de 2018

Aceptado: 13 de noviembre de 2018

Primero en línea: 26 de noviembre 2018

Online First Publication: 26th November 2018

\section{LITERATURE CITED}

Casasola González, J. A. 2006. Phylogenetic relationships of the genera of Epipsocetae (Psocoptera: Psocomorpha). Zootaxa 1194: 1-32.

Casasola González, J. A. \& García Aldrete, A. N. 2002. A taxonomic revision of the genus Goja (Psocoptera: Epipsocidae). Publicaciones Especiales del Instituto de Biología, Universidad Nacional Autónoma de México 18: 1-143.

Enderlein, G. 1911. Die fossilen Copeognathen und ihre Phylogenie. Palaeontographica 58: 279-360.

González-Obando, R., Carrejo-Gironza, N. \& García Aldrete, A. N. 2017. New species of Colombian Triplocania Roesler (Psocodea: 'Psocoptera': Ptiloneuridae). Zootaxa 4336 (1): 1-113.

Lienhard, C. \& Smithers, C. N. 2002. Psocoptera: World Catalogue and Bibliography. Instrumenta Biodiversitatis V. Muséum national d'histoire naturelle. Genéve, Suisse. 745 p.

Mockford, E. L. 1998. Generic definitions and species assignments in the family Epipsocidae (Psocoptera). Insecta Mundi 12 (1\& 2): 81-91.

New, T. R. 1980. Epipsocetae from the Reserva Ducke, Amazonas. Acta Amazonica 10 (1): 179-206.

New, T. R. \& Thornton, I. W. B. 1988. Epipsocetae (Psocoptera) from Peru. Studies on Neotropical Fauna and Environment 23: 225-250.

Silva-Neto, A. M., Rafael, J. A., \& García Aldrete, A. N. 2014. New species of Triplocania Roesler with forewing M3 forked (Psocodea: 'Psocoptera': Ptiloneuridae) from Brazil. Zootaxa 3838 (1): 077-086. 

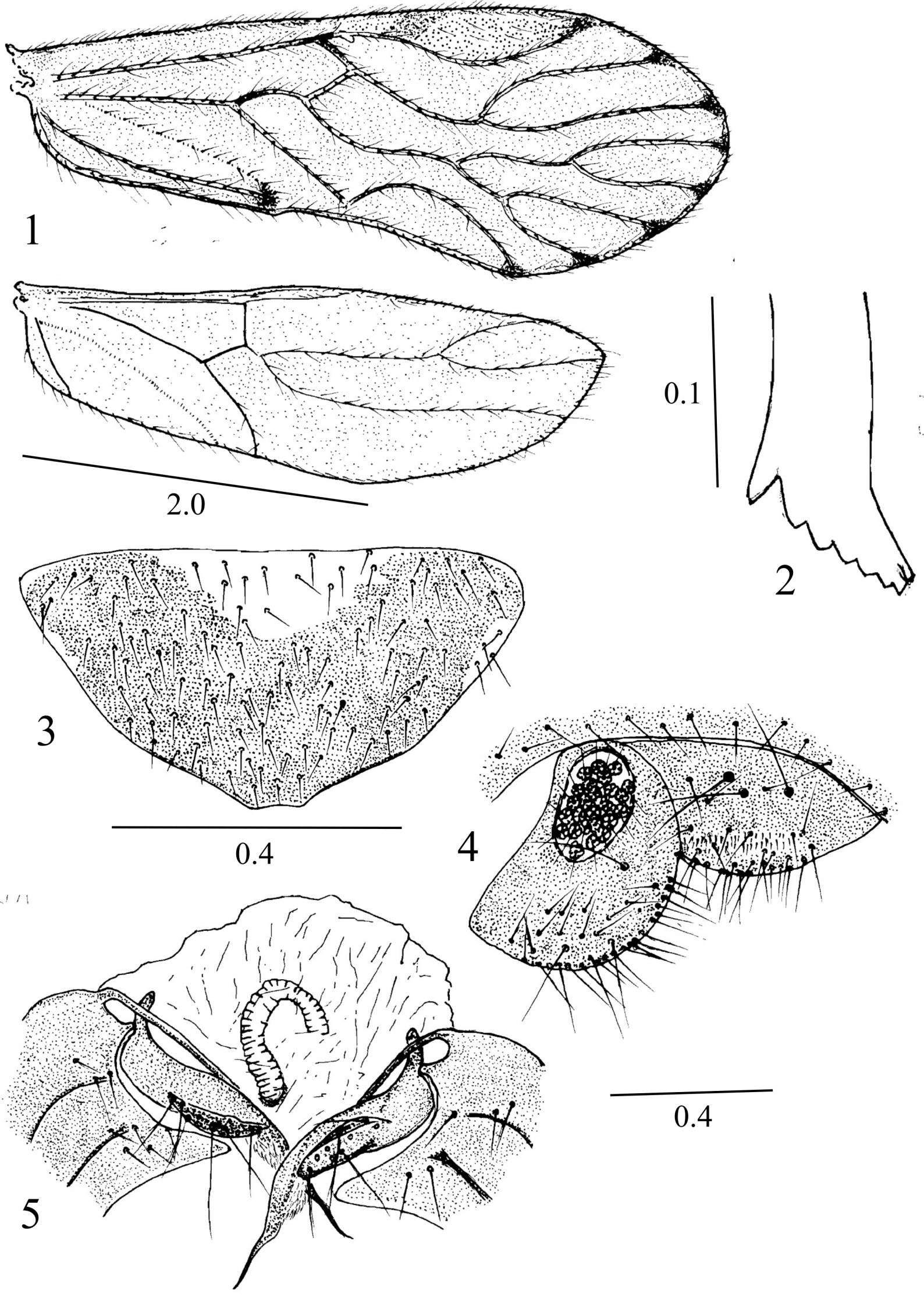

Figures 1-5. Epipsocus moroni n. sp. 1. Fore- and hind- wings. 2. Lacinial tip. 3. Subgenital plate. 4. Left paraproct and epiproct. 5. Gonapophyses and ninth sternum. Scales in mm. Figs 4 and 5 to common scale. 

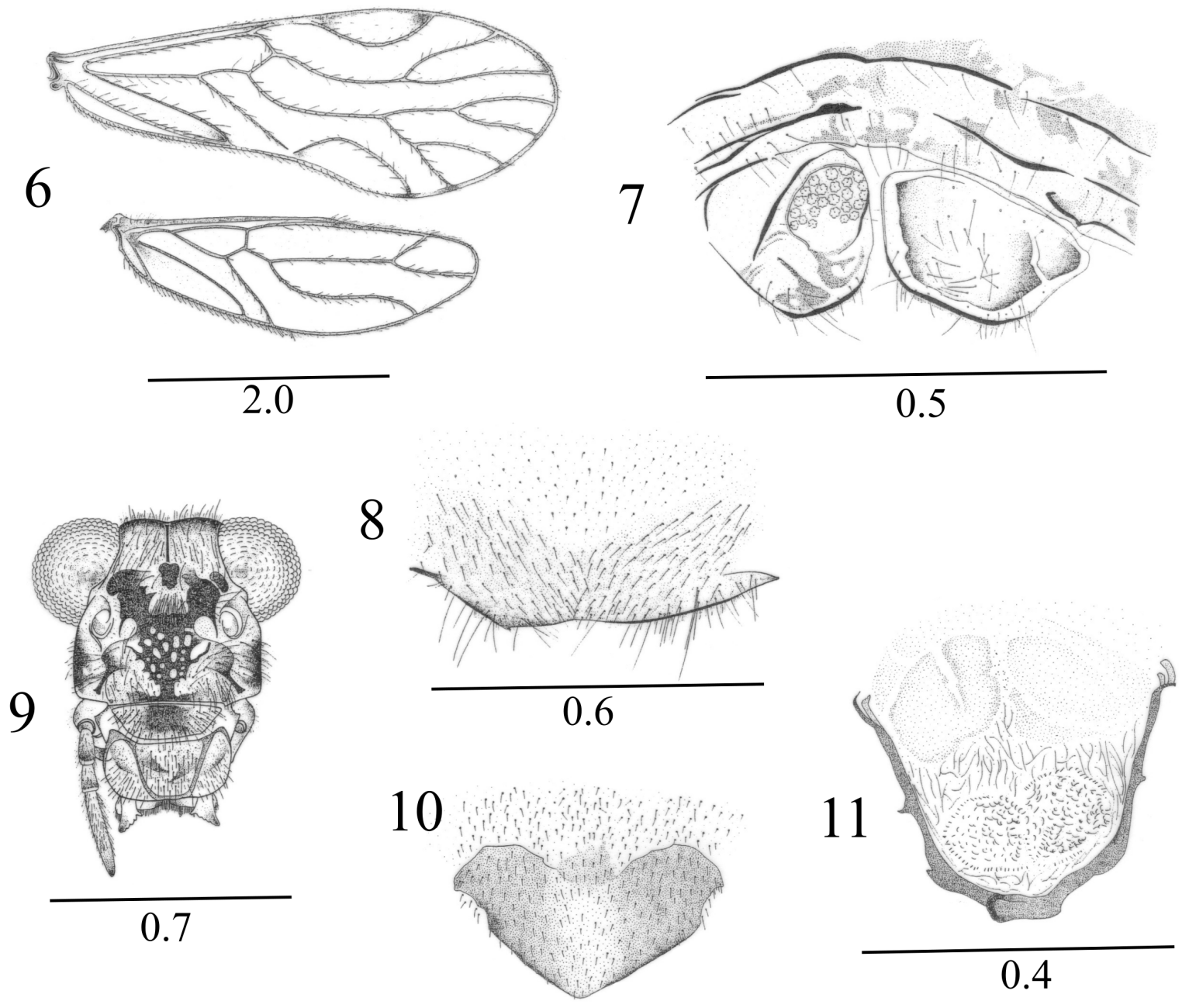

0.7
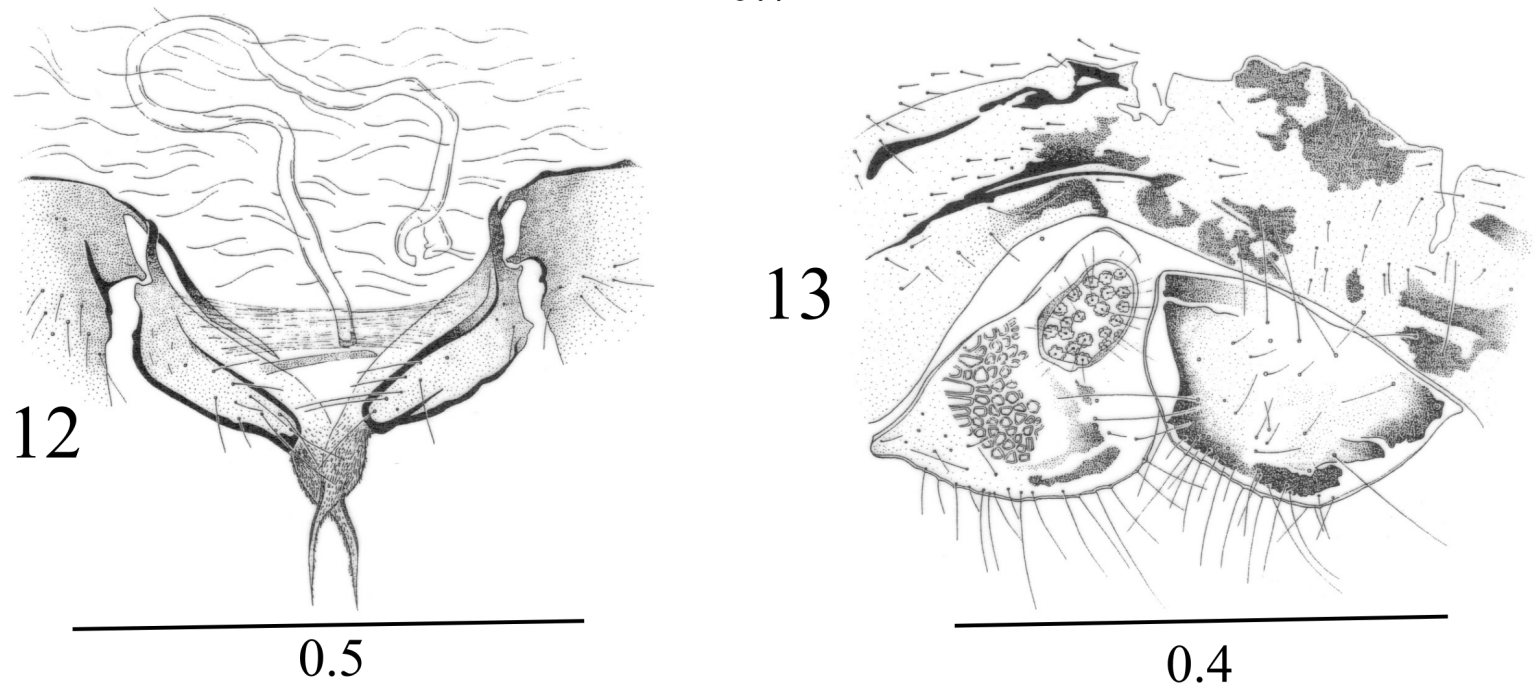

Figures 6-13. Epipsocus reyesi n. sp. 6. Fore- and hind- wings. Male. 7. Clunium, left paraproct and epiproct. Male. 8. Hypandrium. Male. 9. Front view of head. Male. 10. Subgenital plate. Female. 11. Phallosome. Male. 12. Gonapophyses and ninth sternum. Female. 13. Clunium, left paraproct and epiproct. Female. Scales in mm. 

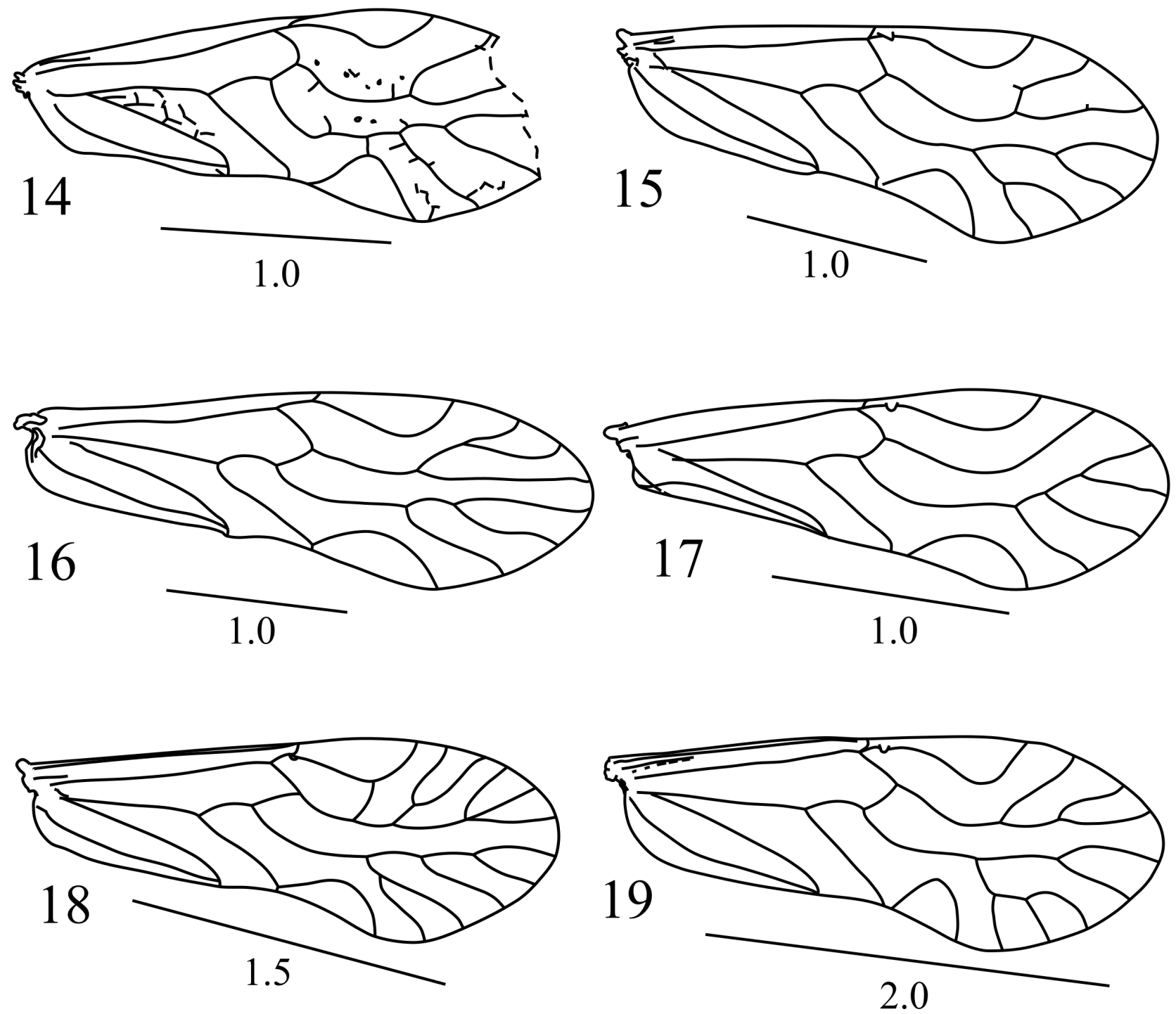

Figures 14-19. Anomalies in the forewing venation of Epipsocus spp. 14. Forewing venation caeciliusid, vein stubs as illustrated, crossvein areola postica-M (ECUADOR. Napo. Waorani Ethnic Reserve, male). 15. Forewing M dichotomously branched, vein stubs on R2+3 and R4+5 (ECUADOR. Napo. Waorani Ethnic Reserve, female). 16. Forewing Rs three-branched, M three-branched (BRAZIL. Amazonas. Río Purus, male). 17. Forewing Rs unbranched, M four-branched (BRAZIL. Pará. Oriximiná. Río Trombetas, male). 18. Forewing Rs five-branched, crossvein Rs-pterostigma, M five-branched (BRAZIL. Amazonas. Manaus. University Campus, female). 19. Forewing Rs three-branched, M five-branched [M3 three-branched] (ECUADOR. Napo. Waorani Ethnic Reserve, female). 